\title{
МАТЕРИЈАЛНА КУЛТУРА СРБА У КОНТЕКСТУ ПОЗАЈМЉЕНИЦА У „ТЕРМИНОЛОГИЈИ КУЋЕ И ПОКУЋСТВА У СЕВЕРНОЈ МЕТОХИЈИ" МИЛЕТЕ БУКУМИРИЋА
}

\begin{abstract}
У раду су са лексичко-семантичког аспекта представљене позајмљенице у Терминологији куће и покућства у северној Метохији Милете Букумирића. Анализа се заснива на корпусу од 320 лексема, које су организоване у дванаест лексичко-семантичких група. Циљ рада јесте да се укаже на порекло позајмљеница и њихову процентуалну заступљеност у оквиру лексичко-семантичких група, као репрезената различитих домена стварности.
\end{abstract}

Кључне речи: позајмљенице, северна Метохија, лексичко-семантичка анализа, семема, статистичка обрада

Полазећи од навода В. Николић да је појам куће „суштински наднационалан и универзалан, док су разлике које међу кућама постоје условљене социјалним, географским, историјским и културним приликама““ [2017: 117], као и од чињенице да појам куће спада у групу основних егзистенцијалних појмова изразито утемељених у нашем свакодневном искуству, која је условила изузетну културну потентност њене језичке ознаке [Николић, 2017: 118], предмет рада биће позајмљенице ${ }^{3}$ у студији Милете Букумирића - Терминологија куће и покућства у северној Метохији. У раду ће назначена тема бити размотрена на корпусу грађе из 30 пунктова одабраних с намером да се равномерно покрије подручје ${ }^{4}$ које се испитује [Букумирић, 2006: 379]. Први део рада бавиће се лексичко-семантичком анализом позајмљеница, док ће у другом делу рада бити приказана статистичка обрада података.

\footnotetext{
${ }^{1}$ Sandrasavic0302@gmail.com

${ }^{2}$ Овај рад настао је у оквиру Пројекта 178020 Дијалектолошка истраживања српског језичког простора, који финансира Министарство просвете, науке и технолошког развоја.

${ }^{3}$ За разлику од термина „страна реч“ за речи које још живе у српском језику или су делимично заборављене бољи термин је „позајмљеница“, јер су се све те речи уклопиле у језички систем српског језика: и по изговору, и по правопису и по флексији [Мразовић, 1996: 210].

${ }_{4}^{4}$ „У вишенационалној средини то није било увек могуће, јер су Срби у време одабирања пунктова у знатној мери били проређени““ [Букумирић, 2006: 380].
} 
Циљ овог рада јесте да статистички прикаже однос позајмљеница ${ }^{5}$ према речима које су словенског порекла. На тај начин видеће се процентуална заступљеност позајмљеница на једном дијалекатском подручју. Порекло оних лексема које као позајмљенице нису наведене у студији Милете Букумирића биће проверено у Речнику српскога књиюсевног језика, као и у Етимологијском рјечнику хрватскога или српскога језика Петра Скока. Претпоставља се да ће, услед многих фактора који су утицали на лексички фонд српског народа на Косову и Метохији, највише бити позајмљеница из турског језика јер, како наводи С. Реметић [2004: 114], „од несловенских језика, на српски дијалекатски мозаик Метохије и Косова, највише су, разуме се, утицали турски и албански“.

Рад ће се базирати на лексичкој обради лексема које се налазе у корпусу. Како истиче С. Петровић [1995: 223], за разлику од фонетских, морфолошких и синтаксичкх особина, које су сматране битним за балкански језички савез, лексички слој, оличен најчешће у позајмљеницама из турског језика, донекле је био занемариван у теоријским студијама. Стога ће се ова анализа вршити у оквиру лексичко-семантичког нивоа јер лексичка анализа може бити веома корисна за балканску лингвистику.Такође, лексика којом се именују реалије из домена традиционалне културе становања део је нематеријалне културне баштине једног народа, а као таква представља важан предмет истраживања у оквиру разних дисциплина. Тематски повезана у једну целину, у овом случају повезана темом куће и покућства, она може пружити увид у многе аспекте језика, како у његову структуру, тако и у његову семантичку позадину [Штрбац, Штрбац, 2019: 16].

У мултиетничким срединама долази до контакта или суживота двеју или више етничких заједница [Радан, 2006: 547], а таква ситуација присутна је и на Косову и Метохији. Током историје, српски живаљ на овом простору долазио је у контакт с Турцима, а касније и с Албанцима. Такви међуетнички контакти као последицу могу имати реципрочне културне утицаје како у материјалној тако и у духовној компоненти живота заједница, уз напомену да једна заједница обично испољава већи утицај на другу [Радан, 2006: 548]. Може се лако претпоставити да ће се у терминологији „која је у непосредној вези са материјалном културом одређеног подручја наћи подоста туђица. Лексичко-терминолошки систем као овај који разматрамо увек је у зависности од различитих ванјезичких фактора, где, пре свега, треба имати на уму економско-социјалне и географско-историјске чиниоце“" [Вуковић, 2000: 125].

Из Терминологије куће и покућства у северној Метохији ексцерпирали смо око $320^{6}$ лексема у домену позајмљеница које су организоване у двана-

\footnotetext{
5 „Један од могућих приступа истраживању лексике из разних страних језика подразумевао би да се таква лексика забележи и класификује према језицима даваоцима. На тај начин добили бисмо инвентар страних речи, као и однос броја речи по језицима““ [Вуковић, 2000: 125].

${ }^{6}$ Фонетизми нису укључени у овај број, али ће о њима бити речи у раду.
} 
ест лексичко-семантичких поља. Таквом аналитичком методом утврђен је приближан проценат позајмљеница које се односе на терминологију куће и покућства у говору северне Метохије. Концепција рада произашла је из намере да се на најадекватнији начин презентује анализирани корпус позајмљеница из говора северне Метохије, и то у оквиру једног конкретног семантичког поља [Петровић, 2012: 25].

За лексику је карактеристично да се преноси на разне начине у друге језике. Узроци таквог процеса могу бити разнолики, попут економских, социјалних, политичких, али и историјских. Најутицајнији фактор на лексику српског народа на Косову и Метохији управо је историјски. Како су наши јужни крајеви тек 1912. године ослобођени од дугог робовања под турском влашћу, разумљиво је што се на овим просторима задржао велики број турских лексема или лексема из других источњачких језика [Вукићевић, 1996: 267]. Како је у питању подручје на којем је утицај турског језика, односно турске лексике (или источњачке преко турског језика) трајао дуго (од XIV до XIX века), у грађи је забележен највећи проценат турцизама. ${ }^{7}$

Према речима С. Ристић [1996: 254] у лексици покућства у попуњавању концептуалних празнина у речнику примарну улогу заузимају позајмљене речи. Стабилност страног лексичког фонда испољава се не само у фреквентнијој употреби већине позајмљених речи него и у њиховој самосталнијој употреби (одсуство или минимално присуство варијантних облика, као и употреба без контактних синонима).

Како је терминологија куће и покућства део културе у ширем смислу - све што је људско друштво створило - представљаће добру грађу за једну врсту лингвистичког истраживања. Феномен сусрета култура, који се сусреће на подручју Косова и Метохије, са лингвистичког аспекта може се посматрати и у домену лескике, где је у фокусу интересовања често била диференцијална лексика условљена разликом у материјалној култури истог језичког простора [Недељков, 2006: 537].

Најобимније семантичко поље јесте 1. Кућа и юени делови. С обзиром на то да је репрезентовано великим бројем семема, самим тим и великим бројем лексема, очекивано је да ће се у овом лексичко-семантичком пољу наћи највећи број позајмљеница [Вуковић, 2000: 125$].{ }^{8}$ Највише је позајмљених речи из турског језика. ${ }^{9}$ Таква ситуација очекивана је на простору северне Метохије када се сагледају сви историјски фактори.

\footnotetext{
${ }^{7}$ Појавом крупнијих поседа бегова и ага, као и масовнијим насељавањем турскх породица, увођењем администрације на турском језику утицало се интензивније на примање лексике и туђица [Божовић, 2016: 38-39].

${ }^{8}$ Нећемо наводити све примере због великог броја лексема страног порекла.

${ }^{9}$ Како наводи Г. Вуковић, и у Војводини је највише позајмљеница доспело у наш језички фонд преко турског језика. Турци нису битније утицали на саму градњу војвођанских кућа, али се њихов утицај огледа у именовању многих делова кућа [2000: 126].
} 
Ово поље подељено је на пет ужих семантичких поља: Tuпови куће, Зид, Кров, Отвори,застори и юихови делови, Соба. Највише је турцизама, чак 48, затим следе германизми, којих у семнатичком пољу Kyћa u њени делови има осам. Нешто је мање речи које су дошле из француског језика - четири, док су три речи у наш језик доспеле посредством грчког језика. Остале позајмљенице, попут речи из латинског, италијанског, албанског, заступљене су са по једним или два примера.

Запазићемо да се у грађи понекад семема може именовати једино лексемом страног порекла. Тако се за семему 'део зида у земљи' једино може чути лексема тёмел’, за који Скок наводи да је балкански турцизам грчког порекла [III: 456]. Семема 'део зида изнад земље од тврђег материјала, бетона или камена и малтера који служи као основица зграде’ репрезентована је лексемом долӓма, која је преузета из турског језика, као и лексемама цุöкла и цио̆кна, које припадају германизмима ${ }^{10}$. За именовање 'места где се спајају два зида’ у употреби је турцизам ћо̆ше $e^{11}$.

Семема 'непечена цигла' бележи се турцизмом ће́рпич12, док се 'печен ћерпич, опека' означава позајмљеницом из немачког језика - циилла.

Турска лексема јапӥја потиснута је из употребе, те се семема 'греде и све друго од дрвета што се употребљава за изградњу крова’ означава дериватом грађа.

Семема 'вертикални отвор на зиду кроз који излази дим изнад крова’ означава се лескемом ӧцак, која је пореклом из турског језика, али и лексемом дймњак, која је словенског порекла, „с тим што турцизам уступа место славенизму“ [Букумирић, 2006: 386]. Лексема пёнцер, која је турског порекла, а употребљава се у значењу 'отвор на зиду кроз који пролази светлост’, потиснута је из употребе и замењена лексемом про́зор словенске провенијенције.

Лексема сáнmpaч ${ }^{13}$, која је у лескички фонд српског језика доспела посредством турског језика, употребљава се у значењу 'простор испред оџака уздигнут око десет центиметара у односу на други део пода', али и у значењу 'гредица укопана у земљаном поду, која је спречавала да се слама растури по незастртом делу'.

Семема ‘горњи део собе обложен даскама' именује се позајмљеницом mӓван, која је балкански турцизам из области градитељства [SkokIII: 448]. У употреби је и германизам шйнда или шйндра.

\footnotetext{
${ }^{10}$ „Ако се погледа за које се реалеме употребљавају германизми, може се констатовати да се углавном ради о оним грађевинским решењима која се могу везати за један каснији период, у којем су се јавиле 'новотарије' приликом грађења и уређења куће“ [Вуковић, 2000: 127].

11 Забележене су и лексеме ћӧшак, ћошниิк, ћӱше, ћушниิк, ћо̂ш.

12 У грађи су забележене и лексеме ће́рпић, ће́рпеч, че́рпич, че́рпић.

${ }^{13} \mathrm{~A}$. Шкаљић наводи да је ова лексема пореклом из санскрита и као једно од значења наводи ce 'ograda, okolica, okvir' [Škaljić, 1966: 549]. Код Скока налазимо објашњење да је у питању балкански турцизам персијског порекла [III: 202].
} 
Германизам шпаијз без изузетка је ушао у лексички фонд српског језика и означава 'просторију у кући за држање и чување намирница'.

Семема 'водоравна површина на степеништу где се гази' претежно се означава лексемом гӓзиште, али и лексемом стёпеница, те је турцизам бӓсамак/басамӓк потиснут из употребе. ${ }^{14}$

Што се тиче позајмљеница из других језика, навешћемо само неколико илустративних примера. Лексичка јединица ћерамйда употребљава се у значењу 'врста старинског, коритастог црепа'. За ову лексему Скок истиче да је балкански грецизам, али да је назив ушао у језик и као турцизам грчког порекла [I: 354]. Позајмљеница из италијанског језика катӓнац означава 'металну направу којом се просторије закључавају спајањем алке и резе'. Англицизам клӧзет/клозетт има значење 'просторија у којој се врши нужда'. Напоредо са позајмљеницом из енглеског језика употребљава се и лексема нужник.

У семантичком пољу 2. Помоћне просторије забележен је свега један турцизам - ӓjam ${ }^{15}$ - са значењем 'наткривен простор пред степеништем'; као и једна лексема која је у лексички фонд нашег језика дошла из румунског. У питању је позајмљеница бачйја која именује 'мању помоћну просторију за прераду млека'. За ову лексему Скок наводи да је балканска реч која је преко румунских номадских пастира прешла преко Карпата [I: 85].

Семантичко поље 3. Предмети у кухињи осим што обухвата лексеме уско везане за ово семантичко поље, садржи још два ужа поља - Прибор за ватру и Прибор за осветљавање.

У овом семантичком пољу турцизама има 16 , германизми су заступљени са четири лексеме, док је забележена једна лексема их мађарског, као и једна лексема из албанског језика.

У оквиру првог дела издвојићемо турцизам сӓч ${ }^{16}$ који има значење 'лимени, испупчени покривач са дршком на средини, који се загрејан и покривен жаром и пепелом ставља преко хлеба у црепуљи, односно преко неког суда у којем се подгрева или пече јело'.

На читавом простору распрострањена је лексема чӱнак ${ }^{17}$ са значењем 'емајлирана или лимена цев која одводи дим од штедњака'. У наш језик доспела је из персијског посредством турског језика.

Турцизам фурйна означава семеме 'простор у штедњаку где гори

${ }^{14}$ Интересантно је да се у Војводини за семему 'степеник' претежно употребљава турцизам басамак, а ређе се именује домаћим лексемама степеник, степен(и)иа или праг. Са нижом френквенцијом јављају се и романизам скалин(а) и германизам штинга [Вуковић 2000: 126].

${ }^{15} \mathrm{У}$ грађи се бележе и ликови äjет и вӓјат.

${ }^{16} \mathrm{O}$ великој заступљености ове лексеме говоре и деривати попут сачаิрник, сӓчарийа, сӓчниц̧а са значењем 'рачваста дрвена, или обична полуга при врху затесана и подешена да се њоме може померити сач под пепелом у водоравном положају и подстицати ватра'.

${ }^{17}$ У грађи су забележени и фонетизми попут чӱғъак, ћӱнак. 
ватра', ‘емајлирана пећ за огрев, која је произведена у фабрици' и 'лимена пећ без шамота, за огрев дрвима, која је произведена у лимарској радионици'. За последње значење у употреби је и позајмљеница из албанског језика - кафторр.

Германизама има веома мало у овом семантичком пољу. Забележени су следећи: шпӧрет са значењем 'метална пећ са пекаром, штедњак, која се користи за грејање просторије и припремање јела, ри́нгла са значењем 'плоча кружног облика која затвара отвор тог облика на плочи штедњака' и ре́рна 'део штедњака у којем се пече'. Из мађарског потиче лексема фијо́ка која се употребљава у значењу 'лимена посуда правоугаоног облика испод ложишта штедњака у коју испада пепео’.

Ужа семантичка поља попут Прибор за ватру и Прибор за осветљавање оскудна су по броју позајмљеница. Лексема ћйбрит, која је пореклом из турског језика, са значењем 'кутија са палидрвцима за паљење ватре' потиснута је из употребе. Веома су распрострањене лексеме фитиิл', која се употребљава у значењу 'платнена врпца у петролеју или фењеру и представља балкански турцизам [SkokI: 520], као и фёъер, односоно 'застакљена лимена светиљка на петролеј која се користи за осветљавање просторија изван собе'.

Као германизам забележена је лексема лаิмnа и њен фонетски лик лаิмба. Ова лекесема има широко распрострањену употребу и означава ‘застакљену светиљку на петролеј, која служи за осветљавање просторија'

У семантичком пољу 4. Намештај заступљен је велики број лексема страног порекла. Од 25 позајмљеница највише је турцизама, чак 13. Германизама има пет (кӧкл'иц̧а, регаิл, офӥнгер, фёдеิрни крёвет, фе́дер), док су забележене свега две лексеме из мађарског језика (фијо́ка, остаิл или астаิл) и по једна позајмљеница из грчког (трапазӓн), енглеског (кӓуч), француског (шифуње̂р или шифоње̂р), италијанског (крёденащ $\left.{ }^{18}\right)$ и латинског (ормаิн). ${ }^{19}$

Као илустративне позајмљенице из турског језика навешћемо следеће: чекмёже, чивйлук, сӧфра, крёвет, душёклак, са́нтрач, ӧтоман, бешийка. Лексема чивйлук ${ }^{20}$ може означавати три семеме, и то 'направу за вешање

18 Увидом у Речник српског књижевног језика установљено је да је ова лексема доспела у наш језик из италијанског. М. Букумирић експлицитно не наводи каквог је порекла креднаи, док Гордана Вуковић коменатрише да је ова лексема дошла из немачког или бар посредством немачког језика [2000: 129].

${ }^{19}$ Однос позајмљеница у овом семантичком пољу другачији је него на простору Војводине. Наиме, у оквиру семантичког поља Собни намештај највише је забележено германизама, док је турцизама знатно мање. Г. Вуковић наводи да се „све те речи одоносе на предмете (односно њихове делове) који су карактеристични за економско и културно развијенији миље“" [2000: 129].

20 Четврта семантичка категорија изведеница суфиксом -лук укључује широк круг лексема у значењу предмета. Изведенице са овим значењем подложне су лексикализацији у великој мери, остајући добрим делом у сфери архаичног и етнографског [Радић, 2001: 69]. 
одеће', ‘дрвени или пластични део кућног намештаја са куком на средини, која се користи за вешање одела' и 'дрвену или гвоздену направу подешену за постељу на којој се спава'.

Иако је удео речи из мађарског језика веома мали, неке од њих показују велику распрострањеност. Семема 'део ормара што се извлачи' на читавом подручју обележава се лексемом фијо́ка, док се реч остаิл (аста̂л) употребљава у значењу 'виши сто правоугаоног облика'

Семантичко поље 5. Судови веома је лексички богато. Подељено је на пет ужих поља према материјалу од којег су саграђени предмети који се користе за спремање, чување и уношење јела и пића: Земљани судови, Дрвени судови, Метални судови, Стаклени судови, Судови од других материјала.

Лексичких позајмљеница из турског језика свакако је највише, чак 30 лексема дошло је у српски лексички фонд преко турског језика или његовим посредством. Германизми су заступљени са седам лексема, док је речи које воде порекло из латинског језика шест. Позајмљенице из осталих језика заступљене су у мањем броју.

У овом семантичком пољу срећу се лексеме којима се означава најнеопходније посуђе или прибор [Вуковић, 2000: 130] попут турцизма чӓнак који се употребљава у значењу 'емајлирани суд из којег једе већи број особа'. За 'земљани суд за ракију, који има дршку, већи отвор с горње и мањи истурен при врху с предње стране' употребљава се лексема ӥбрик која је балкански турцизам персијског порекла [Skok I: 705].

За семему 'емајлирани земљани суд за воду која се користи за пиће' у употреби је лексема из новогрчког језика, конӓта, као и лексема пореклом из латинског, крчаิг. Како наводи Букумирић (2006: 398), позајмљеница из новогрчког има распрострањенију употребу, док се у мањем броју пунктова користи лексема преузета из латинског језика.

Када су у питању дрвени судови, свакако најраспрострањенија лексма јесте бӱре са значењем 'суд за ракију са два утора а испупченим дугама', која је у српски лексички фонд дошла из латинског језика. Као турцизам издвојићемо лексему дёбе ${ }^{2 l}$ која се употребљава двојако, као 'дрвени суд за млеко мале запремине, који се користи за држање млечних производа', и као 'уска а дубока каца која се користи за производњу масла метењем'

Најбројније уже поље јесу Метални судови. Од чак шеснаест турцизама издвојићемо оне који су свакако у најширој употреби попут кӧфа, mencüja, mäc, тигârь, сáнче, чинйја, кӓзан. Германизам ва́нгла² који се упо-

\footnotetext{
${ }^{21}$ Лексема дёбе дошла је из арапског језика посредством турског. А. Шкаљић наводи да је то 'okrugla drvena ili bakrena posuda s poklopcem u kojoj se drži ili nosi sir, kajmak, med itd.; mali mijeh u kome se drži maslo, ulje, med, pekmez i sl.' [1966: 208].

22 „Може се запазити да се речима из немачког језика најчешће обележавају реалеме за које се са сигурношћу може претпоставити да су одраз развијеније материјалне културе“" [Вуковић, 2000: 130].
} 
требљава у значењу 'већи емајлирани суд са двема дршкама, који се обично користи за држање теста док фрементира’ има и облик средњег рода ва́нгло.

У оквиру Стаклених судова навешћемо лексему балонн која се употребљава у значењу 'већи стаклени суд од 5, 10, 20 или 50 литара или суд наведене запремине од пластике' која је пореклом из француског језика, као и германизам флӓша са значењем 'мањи суд за уским грлом'.

Уже семантичко поље Судови од других материјала садржи свега два германизма (ио́ља, тӓцฺна/ та́ц̧на) и два турцизма (финциа̂н, ајдүิк). Лексема финиаิн, која означава 'мањи суд од порцелана из којег се пије кафа', забележена је и у фонетском лику филиаิн. Иако се постепено потискује из употребе, може се чути у говору старијих особа [Букумирић, 2006: 404]. Лексичка јединица ајдүิк употребљава се у значењу 'посуда од посебне врсте тикве на чију је дршку насађена цев дужине до један метар, а на бочној страни лоптастог облика уграђено парче цеви за усисавање ваздуха при вађењу ракије из бурета'.

У семантичком пољу 6. Остали кућни предмети, како је веома лескички богато, очекиван је и велики број позајмљеница. Састоји се из шест ужих поља: Опрема за држање и ношење других предмета, Предмети од прућа, Предмети за припремање хране и пића, Опрема за одржавање хигијене, Сечива, Опрема за друге кућне потребе.

У првом ужем семантичком пољу регистровано је пет лексема које су у српски језички фонд дошле из страног језика, и то две лексеме пореклом из латинског, и по једна лексема из турског, немачког и мађарског језика. Као најфреквентнију издвојићемо лексему конӧпче која се употребљава у значењу 'коноп од упреденог вуненог канапа којим се стеже бреме на леђима'. У Речнику српскога књижевног језика наводи се да је ова лексема латинског порекла, док у Терминологији куће и покућства у северној Метохији тај податак изостаје. Германизам цее́гер среће се на целом подручју северне Метохије и означава реалему која је саставни део материјалне културе.

Семантичко поље Предмети од прућа садржи три лексеме из турског језика и једну позајмљеницу из немачког језика. 'Котарица са већом дршком полукружног облика, која служи за држање или ношење разних предмета' именује се лексемом ко́рn ${ }^{23}$ која је у наш лексички фонд доспела из немачког језика. Овај германизам има широку распрострањеност која се огледа и у његовој полисемији, па је забележено и значење “корпа крушкастог облика од неогуљеног прућа са дршком полукружног облика, израђена у домаћој изради, а користи се обично за брање воћа и поврћа'.

У ужем семантичком пољу Предмети за припремање хране и пића нашао се приличан број позајмљеница, од тога пет турцизама, две лексеме из

\footnotetext{
${ }^{23}$ Адаптација ове позајмљенице у лексички фонд српског језика огледа се и у њеној деривацији, па је у грађи забележен и деминутив корпица који се употребљава у значењу 'мала корпа од неогуљеног прућа израђена у домаћој радиности, у којој су обично пастирице носиле плетиво и ужину'.
} 
латинског језика, и по једна из албанског, грчког, француског и италијанског језика.

Као најзаступљенији турцизам издвојићемо лексему кӓзан, која се употребљава у значењу 'машина за дестилацију ракије', као и њене хибридне форме, попут старйнскй кӓзан, зйдани кӓзан, зёмл'ани кӓзан са значењем ‘непокретни казан за дестилацију ракије' и машиิнски кӓзан који означава 'усавршенији казан, који је уграђен у лименој пећи и може се померати с места на место’. За ову лексему П. Скок истиче да је балкански турцизам из терминологије алата [II: 69].

Из албанског језика преузета је лексема кафторр која се употребљава у значењу 'лимено ложиште око котла на машинском казану'. Са овим значењем употребљава се и турцизам фурйна са својим фонетским ликовима фарйна и форуина. Иако М. Букумирић то експлицитно не наводи, за значење 'посуда у средини табарке машинског казана за дестилацију ракије, која се састоји од ваљкасте бакарне посуде или спиралне бакарне цеви где се кондензује пара алкохола' употребљавају се лексеме anapâm, која је пореклом из латинског језика, и резерваิр, која је у лескички фонд српског језика доспела из француског језика.

Семантичко поље Опрема за одржавање хигијене оскудно је и на плану семема, као и на плану лексема [в. Вуковић, 2000: 131]. Назив са́ндук ${ }^{24}$ за 'дрвену посуду у коју се слагао веш за прање цеђом' балкански је турцизам арапског порекла [Skok III: 200]. 'Метална направа која се загрева жаром или струјом, а служи за глачање одеће’ означава се германизмом пе́zла $a^{25}$. Из грађе ћемо издвојити и лексему салве́ma ${ }^{26}$, која потиче из италијанског језика, а употребљава се у значењу 'крпа за брисање посуђа'.

Само три позајмљенице, и то турског порекла, забележене су у ужем сематичком пољу Сечива. У питању су лексеме чакӥја, сатӓра и аваิн ${ }^{27}$ за које у Терминологији куће и покућства у северној Метохији није наведено из ког језика потичу.

Семантичко поље Опрема за друге кућне потребе обилује већим бројем позајмљеница. Забележене су три лексеме из немачког језика (кýzла,

\footnotetext{
24 Лексема са́ндук у дошла је у српски лексички фонд из арапског језика посредством турског и има значење 'drveni sanduk, škrinja' [Škaljić, 1966: 548]. У грађи је забележен и деминутив сандуче.

${ }^{25}$ У грађи је забележен и фонетски лик пе́zло. За ову лексему М. Букумирић експлицитно не наводи да је у питању позајмљеница из немачког језика.

${ }^{26}$ М. Букумирић [2006: 408] наводи да је ова лексема у наш језик ушла после Другог светског рата.

27 Лексема аван потиче од турске речи хаван која је пореклом из персијског језика. Као једно од значења наводи се 'sprava za križanje duhana' [Škaljić, 1966: 322], а такво значење забележено је и у Терминологији куће и покућства у северној Метохији.
} 
муштӥкла ${ }^{28}$, шла́јпек) две из турског (кӓнтар, ћёса), и једна из француског (mpӥјер). За семему 'кожна направа у којој се држи новац' употребљава се германизам шла́јпек са фонетским ликовима шла́jпак, шла́јпик. Како наводи Букумирић [2006: 410], „напоредо са овом лексемом употребљава се и посуђеница романског порекла батифӧка, која је знатно мање фреквентна од наведеног германизма“. Широку употребу има „балкански турцизам романског подријетла“ (Skok II: 35) кӓнтар који се употребљава у значењу “направа за мерење тежине која се састоји од куке за држање, полуге са подеоцима, покретне кугле, две куке и таса окаченог о три ланца'.

Семантичко поље 7. Прибор за рад репрезентовано је великим бројем позајмљеница. Подељено је на три ужа поља - Прибор за домаћу радиност, Прибор за рад у пољу, Прибор за гајење животиња.

У семантичком пољу Прибор за домаћу радиност, иако је лексички веома богато, нема много лексема страног порекла, већ преовлађују оне словенског порекла. Ипак, највише је речи које су у наш лексички фонд дошле из турског или посредством турског језика. Тако се лексема чёкрк употребљава у значењу 'проста направа од точка на ручни погон, који је канапом спојен са осовином на коју се постављају цевке за мотање потке'. Широку употребу има и лексема кӓлем са значењем 'дрвена цевчица са ободима на коју се мота памучна основа', која је из грчког језика посредством турског ушла у српски језички фонд.

Прибор за рад у пољу обилује како домаћим лексемама, тако и позајмљеницама, те је у грађи забележен велики број турцизама - чак једанаест. Са друге стране, само су се три позајмљенице из немачког језика нашле у оквиру овог ужег семантичког поља.

Значење 'гвоздена алатка са дрвеним држалом, којом се крчи ситногорица и која служи за копање тврде подлоге’ обележава се двема лексемама - турцизмом бӱдак и германизмом крӓмn. У већини пунктова на подручју северне Метохије лексемом чивӥја означава се 'дрвени клин у металном прстену којим се коса учвршћује за косиште’. Ова лексичка јединица представља балкански турцизам из области алата [Skok I: 330], а забележена је и у фонетском лику чевӥја. Значење 'посуда са водом за држање бруса при косидби' може бити репрезентована германизмом каิнта, али и турцизмима кӧфа и чутӥра.

У семнатичком ужем пољу Прибор за гајење животиња поред девет турцизама нашле су се три позајмљенице из немачког језика (каิјла, крӓба, праิнге) и по једна позајмљеница из албанског (л'ÿ $\left.z^{29}\right)$ и новогрчког (сама̂p).

Значење ‘механизам којим се затвара огрљак за овчије звоно’ означава се првенствено позајмљеницама из турског језика: чивйја, чевӥја, баглӓма,

\footnotetext{
${ }^{28}$ У грађи се налази и фонетски лик муштӥка.

${ }^{29}$ „Позајмљеница из албанског језика употребљава се на западном делу подручја које се овде испитује“" [Букумирић, 2006: 417].
} 
nул'ӥја, али и германизмом каิјла, који се бележи као алтернација турцизму чивӥја [в. Букумирић, 2006: 418]. Балкански турцизам из терминологије коња [Skok III: 554] зёнгӥja, али и фонетски лик узёнгӥја, користи се како би се именовала 'метална папуча која виси о каишу седла'.

У семантичком пољу 8. Обућа од страних речи најбројније су оне из турског језика. Многе од тих лексема и данас су у широкој употреби, попут: чӥзма, nanÿча, чара̄na, кӓищ. На подручју северне Метохије веома је распрострањен турцизам нанула ${ }^{30}$, који се употребљава у значењу 'врста папуче од дрвета са каишем на предњем делу’, али у фонетском лику на̄лӓна или на̄лӱна. Из мађарског језика у наш доспела је лексема цийпела, док се сӓндала везује за грчку провенијенцију. Позајмљеница гёта, за коју М. Букумирић наводи да је италијанског порекла, има свој синоним који је пореклом из турског језика - калчйна ${ }^{31}$.

У веома богатом семантичком пољу 9. Одећа обиман је и број речи које нису словенског порекла. Лексика из турског језика највише је заступљена и сеже до двадесет и пет позајмљеница, затим следе речи које су у наш језик доспеле из француског, чак шест лексема. Нешто је мање италијанизама и англицизама - по три, док је лексика мађарске провенијенције заступљена са две лексеме. У грађи је забележена једна лексема из немачког, једна из албанског језика и једна лексема која је латинског порекла.

Највише речи примљено је посредством турског језика. Тако се за семему 'исхеклани украс на бочним и доњој страни вијанке' користе две лексеме турског порекла - чйкма и рёшма ${ }^{32}$, мада њихова распрострањеност није широка (само у неколико пунктова). За именовање 'дела женске одеће украшен везом, а носио се преко сукње са задње стране’ користи се лексема бошча која се употребљава у гласовном лику бӧкча [Букумирић 2006: 422]. Лексема кӓиш означава 'кожни опасач којим се потпасују мушкарци у струку’ и присутна је на целом подручју северне Метохије. 'Сукнене панталоне украшене гајтанима' називају се чакшйре ${ }^{33}$. Од осталих турцизама широко су распростарњене лексеме попут: га́јтан 'исплетена врпца од вуненог конца за украс једне врсте мушких панталона', циёn 'прорез на одећи са кесицом у којој се носе ситне ствари', учкүิр $p^{34}$ 'врпца увучена у доњи део гаћа, којим се оне стежу око паса', дүิгме и пү̂л'ка (пул 'ӥја) 'предмет, обично округлог облика, који служи за закопчавање одеће', памукл'ӥја' 35 'прслук од платна

\footnotetext{
${ }^{30}$ У грађи су забележени и фонетски ликови на̄лӓна и натлӱна.

${ }^{31}$ А. Шкаљић овај турцизам доводи у везу са италијанизмом calzane 'sobna obuća, nazuvak' [1966: 386].

32 Забележен је и лик грёшма.

33 Забележени су и фонетски ликови чашӥре, чекшйре, чешйре.

${ }^{34} \mathrm{У}$ грађи се налазе и фонетски ликови очкүิp, ушкүิр, уmŷp.

${ }^{35}$ Суфиксом -лија граде се углавном изведенице које означавају особу. У класи предмета, па
} 
који је испуњен памуком', јелёче 'кратки мушки, као и женски прслук украшен везом', те́рлак ${ }^{36}$ 'плића, плетена капа од памука', ша̄мӥја 'једнобојна памучна крпа, али декорисана местимично на ивицама, односно на угловима, коју жене носе на глави' и др.

Из француског језика доспеле су речи као што су блу́за 'горњи део мушког одела', костиิм 'женска штофана блуза', мажётна 'доњи, подврнути део ногавица од панталона', кол'иিр 'део кошуље око изреза за врат', берётка ${ }^{37}$ ‘округла чохана капа', качке̂m 'врста капе са штитом на предњој страни'.

Позајмљенице из енглеског језика заступљене су са свега три лексеме и то: пица́ма која има значење 'део одеће који се облачи при спавању', це́мпер ${ }^{38}$ у значењу 'део одеће од плетива са рукавима' и пйловер 'џемпер без рукава'.

У грађи се налазе и италијанизми рӓща, пантало́не, кӓпа, као и хунгаризми кецеёл' $a^{39}$ и бӱнд $a^{40}$. По једна лексема ушла је у српски лексички фонд посредством албанског и латинског језика и то те̂ще у занчењу 'општи назив за одећу', односно патёнт са значењем 'патентни затварач на одећи место дугмади, рајсфершлус'.

Удео речи из немачког језика сасвим је незнатан у овом семантичком пољу. Забележена је лексема $и л$ 'üus ${ }^{41}$ која се употребљава у значењу 'отвор на горњем делу панталона са предње стране'.

Семантичко поље 10. Постељина садржи 18 позајмљеница, и то 13 турцизама, два германизма, док је удео осталих лексема страног порекла незнатан - по једна позајмљеница из француског, италијанског и мађарског језика.

Од турских лексема забележене су следеће: дӱшек, ћёбе, јо́рган, душёче (душёкче), ираิм (ираิмче), душёма, ча́ршаф (ча́ршав), јӓстук, мушёма, ћил'иิм (ћел'иิм), черрга, сеиа́да, асӱра. Веома распрострањена лексема ча́риафф употребљава се у значењу 'простирач од најфинијег платна', али и у значењу 'платнени покривач за сто’.

и објеката у ширем смислу, изведенице су ретке у књижевном језику и углавном припадају архаизмима, широко заступљеним међу народним говорима [Радић, 2001: 39].

${ }^{36}$ Претпостављамо да је у питању лексема турског порекла. У Речнику српског књижевног језика налази се лексема терлук са значењем, 'лака женска кућна папуча од фине танке коже извезена златом, сребром или свилом'. Код П. Скока налазимо лексему терлуци која, између осталих, има и значење 'od konca ispletena kapa ispod fesa ili kačketa' [III: 461].

37 Забележени су и фонетски ликови барётка, борётка.

${ }^{38}$ Из грађе је ексцерпирана и лексема цемпёрче која се употребљава у значењу 'дечји џемпер'.

${ }^{39}$ Бележи се и фонетски лик кицеёл'.

40 Лексмеа ћӱрак, која је турског порекла, има исто значење, али је у потпуности потиснута на подручју северне Метохије [Букумирић, 2006: 424].

${ }^{41} \mathrm{У}$ грађи се налази и фонести лик шнийц. 
Германизмима се обележавају углавном оне реалеме које су касније ушле у српски језички фонд и постале уобичајене на нашем терену [Вуковић, 2000: 132]. Такве су лексеме дёкица, са значењем 'украсни покривач за кревет изаткан од вунене пређе' и тёпик, са значењем 'велики застирач фабричне израде за застирање пода'.

Од осталих позајмљеница забалежена је лексема мил'е̂, која се употребљава у значењу 'исхеклани покривач за сто', која је у наш лексички фонд доспела из француског језика. Италијанизам канӓваи има значење 'дуга, уска плетена тканина на којој се у пољу радницима поставља јело'. Од мађарских речи забележена је само лексема иӓкл'ица ${ }^{42}$ са значењем 'украшена зидна торбица за ситне ствари'. ${ }^{43}$

Семантичко поље 11. Окућница одликује се релативно богатим лексичким слојем, али је туђица веома мало - свега два турцизма и два германизма, који су одомаћени на читавом терену.

Лексема баิшта ${ }^{44}$ турске провенијенције употребљава се у значењу ‘део окућнице где се гаји поврће'. 'Просторија у којој се складишти пшеница, без обзира на облик и величину, тј. да ли је у питању помоћна просторија у довришту, или већи сандук за ту намену смештен у некој просторији у кући' именује се лексемом ӓмбар која је балкански турцизам персијског порекла [Skok I: 33].

Речи из немачког језика широко су распрострањене не само на простору северне Метохије него и на читавом подручју српског језика. Лексема плӓи има заначење 'место где се прави кућа', док се 'озидана и покривена просторија за узгој стоке' именује лексемом штӓла.

Последње семантичко поље 12. Дворишне ограде веома је оскудно, те није забележен ни велики број позајмљеница. Иако су забележена само три турцизма, аввл 'ӥја, крёвет и тарӓба, њихова употреба потврђена је скоро на читавом простору северне Метохије. Албанизам ћоिндра употребљава се у значењу 'дебљи, косо пободени, само при врху уплетени колац у дворишној огради'. Исто значење има и позајмљеница штӥл'е за коју Милета Букумирић не наводи порекло [2006: 429].

Како је у питању један од говора на тлу Косова и Метохије, оправдано је говорити о језичкој интерференцији. Српски говори на овом подручју у сталном су суживоту са албанским, а и турским становништвом, па

\footnotetext{
${ }^{42}$ Претпостављамо да је у корену речи хунгаризам цак.

${ }^{43}$ У раду Г. Вуковић Туђице у терминологији куће и покућства запажамо да је у оквиру семантичког поља 23. Постељина и 24. Прекривачи, простирке и платнене кесе присутан велики број хунгаризама (буље, бундаш, ванкуш, губа, губер, дереклија, дорои, дуња, лапедов, ронђом) [2000: 132], док на простору северне Метохије то није случај. Овакво стање најбоље се може објаснити географским фактором и великим утицајем мађарске културе на становнике Војводине.

${ }_{44}$ Забележен је и фонетски лик баิкча.
} 
је међујезичка интерференција и очекивана [Марковић, 2009: 270]. Стога је и неизбежан велики број позајмљеница, како оних које су постале део стандардног српског језика, тако и оних које су карактеристичне за ово дијалекатско подручје.

Велики број турцизама забележен је у првом семантичком пољу Tunoви куће - чак 48. По броју турцизама издвајају се и треће, пето, шето, седмо и девето семантичко поље. Када су у питању предмети у кухињи, судови, кућни предмети, прибор за рад, постељина и одећа, утицај турског језика био је доминантан како би се одређене реалеме именовале.

Гермнизама највише има у првом семантичком пољу (осам лексема), затим у четвртом, петом и шестом (пет, седам и шест лексема). У осталим семантичким пољима позајмљенице из немачког језика заступељне су у мањем броју. У пољу 2. Помоћне просторије, које је веома оскудно када су у питању речи страног порекла, германизама уопште нема.

У билингвалној средини као што је севернометохијска поред бројних турцизама употребљавају се и речи које су у наш језик дошле из албанског језика. Имајући у виду прошлост нашег народа, посебно народа на Косову и Метохији, разумљиво је што се у нашем језику одомаћио велики број варваризама [Букумирић, 2000: 163].

Најшири дијапазон позајмљених лексема присутан је у семантичком пољу 9. Одећа. Ту се поред великог броја турцизама, налазе и речи из немачког, албанског, енглеског, мађарског, италијанског, француског и латинског језика. Како су реалеме које се тичу одевних предмета улазиле у лексички фонд појавом нових модних трендова, овакво лексичко шаренило очекивано је и оправдано.
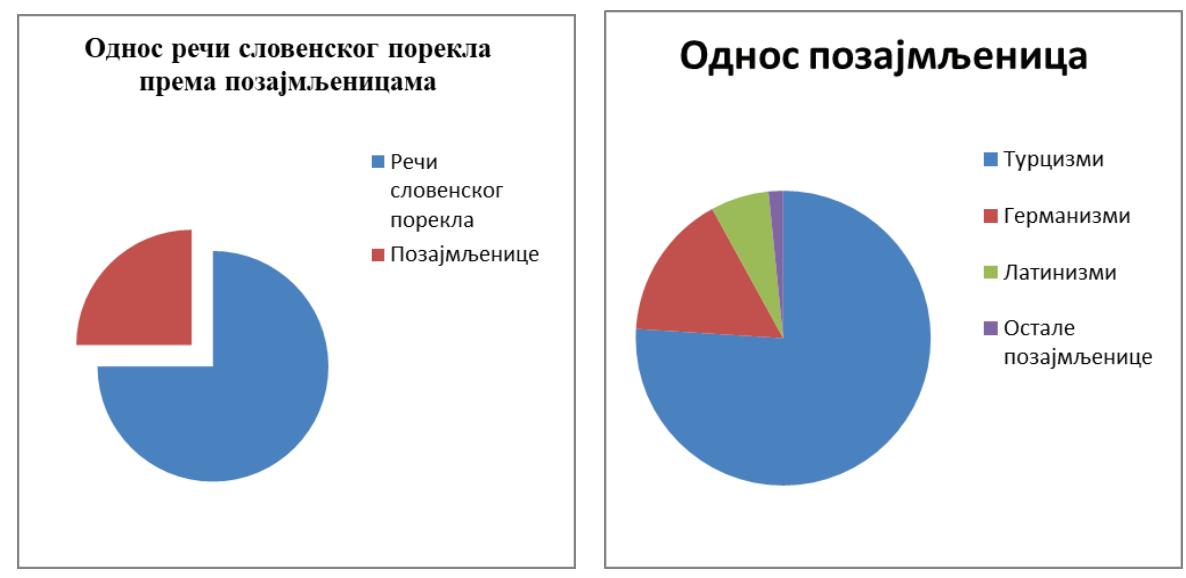

Анализа семантичких поља доводи до закључка да позајмљеница у Терминологији куће и покућства у северној Метохији има у великом броју. Оне нису у сваком семантичком пољу сразмерно прерасподељене, па се 
на тај начин може утврдити у којим су терминолошким скуповима најзаступљеније лексеме страног порекла. Иако су неке позајмљенице потиснуле домаће лексеме, број домаћих лексема свакако је већи од позајмљеница у било ком анализираном терминолошком сегменту куће и покућства. О овоме сведочи податак да је однос лексема словенског порекла према речима које су у српски лексички фонд дошле из других језика 75 \% према 25 \%.

Највише је турцизама - забележено је преко 200 лексема које су пореклом из турског језика или су у српски језички фонд дошле посредством турског, те се хипотеза с почетка рада испоставила као тачна. Следећи по проценту заступљености су германизми - нешто више од 40 лексема. Са свега 1, 6 процената заступљене су лексеме из латинског језика.

Позајмљенице из турског језика углавном се везују за дубљу прошлост, попут семантичког поља 1. Типови куће или 5. Судови. Лексеме из немачког, француског, италијанског и енглеског везују се за реалеме новијег датума, па су очекивано заступљене у семантичким пољима која се тичу намештаја, одеће, предмета у кухињи. Хунгаризама нема у великом броју, али су неке лексеме широко распрострањене, попут позајмљеница фијо́ка, иүйпела, бӱнда. У грађи су забележени грецизми као што су лексеме пӓтос, са̄ндӓла, кӱтлача са широким уделом не само на простору северне Метохије већ су део и стандардног српског језика.

На крају, треба споменути да се у периферијским говорима лексеме страног порекла чешће употребаљавају као последица међујезичких, економских, социјалних, политичких и историјских фактора. Овакво стање очекивано је и на подручју северне Метохије, као стожеру сусрета неколико култура током вишевековне бурне историје српског народа.

\section{Извор}

Букумирић, 2006: Милета Букумирић, Терминологија куће и покућства у северној Метохији, Српски дијалектолошки зборник, LIII, Београд.

\section{Литература}

Божовић, 2009: М. Божовић, Неке заједничке појаве у српском, албанском и турском језику на Косову и Метохији. Ниш: Годишњак за српски језик и књижевност, 37-45.

Букумирић, 2000: М. Букумирић, О неким позајмљеницама из албанског језика у говорима северне Метохије. Београд: Јужнословенски филолог, LVI, 163-170.

Вукићевић, 1996: М. Вукићевић, Турцизми у називима покућства у говору Приштине и њене околине, у: О лексичким позајмљеницама. Суботица - Београд, 269-277. 
Вуковић, 2000: Г. Вуковић, Туђице у терминологији куће и покућства, у: 3борник Матице српске за филологију и лингвистику. Нови Сад: Матица српска, 125-136.

Марковић, 2009: Ј. Марковић, Балакнизми у српским говорима Косова и Метохије. Ниш: Годишњак за српски језик и књижевност, 269-277.

Мразовић, 1996: П. Мразовић, Германизми у говорном језику Војвођана, у: $O$ лексичким позајмљеницама. Суботица - Београд, 209-231.

Недељков, 2006: Љ. Недељков, Модели култура - проблем језичке експликације, у: Сусрет култура. Нови Сад: Филозофски факултет у Новом Саду, 527-545.

Николић, 2017: В. Николић, Лингвокултуролошка слика куће у речницима српског језика. Београд: Кьижевност и језик, LXIV/1-2, 117-135.

Петровић, 1995: С. Петровић, Неки турцизми у српскохрватској кулинарској терминологији. Београд: Јужнословенски филолог, LI, 223-232.

Петровић, 2012: С. Петровић, Турцизми у српском призренском говору - на метријалу из рукописне збирке речи Димитрија Чемерикића. Београд: Институт за српски језик САНУ.

Радан, 2006: М. Радан, Лексичке позајмљенице у сфери куће и покућства у српским говорима из румунског Баната као одраз прожимања култура, у: $C y$ срет култура. Нови Сад: Филозофски факултет у Новом Саду, 547-555.

Радић, 2001: П. Радић. Турски суфикси у српском језику, Београд: Институт за српски језик САНУ.

РМС: Речник српскохрватског књижевног језика, 1-6, Нови Сад, 1990.

Реметић, 2004: С. Реметић, Српски народни говори Косова и Метохије у светлу међујезичке и међудијалекатске интерференције. Београд: Јужнословенски филолог, LX, 113-123.

Ристић, 1996: Стана Ристић, Лексика покућства страног порекла у речницима предвуковског времена, у: О лексичким позајмљеницама, Суботица - Београд, 253-269.

Штрбац, Штрбац, 2019: Г. Штрбац и С. Штрбац, Терминологија куће и покућства у ваљевској Подгорини. Нови Сад: Зборник радова Филозофског факултета у Новом Саду, 15-23.

Skok, 1971-1974: P. Skok, Etimologijski rječnik hrvatskoga ili srpskoga jezika, knj. I-IV. Zagreb: [JAZU].

Škaljić, 1966: A. Škaljić, Turcizmi u srpskohrvatskom jeziku, Sarajevo: [Svjetlost]. 
Sandra Savić

\section{MATERIAL CULTURE OF THE SERBS IN THE CONTEXT OF LOANWORDS IN "TERMINOLOGY OF HOUSE AND FURNITURE IN NORTHERN METOHIJA" BY MILETA BUKUMIRIĆ}

\section{Summary}

The paper presents loanwords in the Terminology of home and furniture in northernMetohija by Mileta Bukumiric from the lexical-semantic point of view. The analysis is based on a corpus of 320 lexemes, organized into twelve lexicalsemantic groups. The aim of the paper is to point out the origin of the loanwords and their percentage representation within the lexical-semantic groups, as representatives of different domains of reality.

Key words: loanwords, Norhern Metohija, lexical-semantic analysis, semems, statistical interpretation. 